\title{
Pengaruh Berbagai Media Tanam Terhadap Pertumbuhan dan Kadar Pigmen Microgreens Selada
}

\author{
Silla Sisriana, Suryani, dan Siti M. Sholihah \\ Program Studi Agroteknologi Fakultas Pertanian Universitas Respati Indonesia \\ Email : sillariana31@gmail.com
}

\begin{abstract}
ABSTRAK
Microgreens merupakan tanaman yang dipanen saat berusia 7-14 hari setelah semai yang memiliki kandungan nutrisi lebih banyak dibanding tanaman yang berusia dewasa. Microgreens memiliki kandungan senyawa seperti alkaloid, klorofil, antosianin, dan karotenoid, yang berperan sebagai antioksidan. Salah satu sayuran yang bisa ditanam secara microgreens yaitu selada.. Media tanam mempengaruhi ketersediaan air, serta ketersediaan unsur hara untuk pertumbuhan dan pembentukan senyawa fitokimia. Penelitian ini bertujuan untuk mengetahui pengaruh perbedaan media tanam terhadap pertumbuhan dan kadar pigmen pada microgreens selada. Penelitian ini dilaksanakan di kebun percobaan kampus B, Universitas Respati Indonesia, pada bulan Februari hingga September 2021. Rancangan yang digunakan yaitu Rancangan Acak Kelompok (RAK), dengan 1 faktor (media tanam), yang terdiri atas 5 perlakuan yaitu : M1 (Cocopeat), M2 (Vermikulit), M3 ( Perlite), dan M4 ( Arang sekam) yang diulang 4 kali, setiap perlakuan diberi penambahan nutrisi $A B$ mix dengan konsentrasi 500 ppm. Parameter yang diamati meliputi persentase perkecambahan, tinggi tanaman, jumlah daun, berat basah tanaman, kadar total klorofil, kadar karotenoid, serta kadar antosianin. Hasil penelitian menunjukkan bahwa perlakuan perbedaan media tanam berpengaruh terhadap persentase perkecambahan, tinggi tanaman, berat basah tanaman, kadar total klorofil, dan kadar karotenoid. Perlakuan media tanam M2 (vermikulit) memberikan hasil terbaik pada persentase perkecambahan $(84,05 \%)$, tinggi tanaman $(8,16 \mathrm{~cm})$, Berat basah $(4,61 \mathrm{~g} / 100$ butir), kadar total klorofil $(0,81$ $\mathrm{mg} / \mathrm{g})$, dan kadar karotenoid $(0,12 \mathrm{mg} / \mathrm{g})$.
\end{abstract}

Kata kunci : Microgreens, Selada, Media Tanam, Pertumbuhan, Pigmen.

\section{Abstract}

Microgreens are plants that are harvested at the age of 7-14 days after sowing which contain more nutrients than mature plants. Microgreens contain compounds such as alkaloids, chlorophyll, anthocyanins, and carotenoids, which act as antioxidants. One of the vegetables that can be grown using microgreens is lettuce. The growing medium affects the availability of water, as well as the availability of nutrients for growth and the formation of phytochemical compounds. This study aims to determine the effect of different growing media on the growth and pigment content of lettuce microgreens. This research was carried out in the experimental garden of Campus B, Universitas Respati Indonesia, from February to July 2021. The design used was a Randomized Block Design (RAK), with 1 factor (planting media), which consisted of 5 treatments, namely: M1 (Cocopeat), M2 (Vermiculite), M3 (Perlite), and M4 (Husk charcoal) which were repeated 4 times, each treatment was given the addition of $A B$ mix nutrients with a concentration of $500 \mathrm{ppm}$. Parameters observed included germination percentage, plant height, number of leaves, plant wet weight, total chlorophyll content, carotenoid content, and anthocyanin content. The results showed that the treatment of different planting media affected the percentage of germination, plant height, plant wet weight, total chlorophyll content, and carotenoid content. Treatment of growing media M2 (vermiculite) gave the best results on the 
percentage of germination $(84.05 \%)$, plant height $(8.16 \mathrm{~cm})$, wet weight $(4.61 \mathrm{~g} / 100$ grains), total chlorophyll content $(0.81 \mathrm{mg} / \mathrm{g})$, and carotenoid content $(0.12 \mathrm{mg} / \mathrm{g})$.

Keywords : Microgreens, Lettuce, Growing Media, Growth, Pigment.

\section{PENDAHULUAN}

Microgreens merupakan bibit muda dari tumbuh-tumbuhan, sayuran, kacangkacangan, dan biji-bijian yang dipanen pada usia yang sangat belia, berksar 7-14 hari setelah semai. Tanaman kecil ini ditanam untuk tahap daun sejati pertama. Jenis tanaman seperti gandum, coriander, brokoli jika dijadikan microgreen dapat dipanen setelah tingginya 4-8 cm [1]. Microgreens sendiri sebenarnya adalah tunas dari aneka tanaman sayur. Semua jenis bibit sayur yang berdaun bisa dikembangkan menjadi tanaman microgreens [3].

Kandungan gizi dan nutrisi microgreens lebih tinggi dibandingkan dengan tanaman dewasa [21]. Microgreens merupakan salah satu jenis makanan yang saat ini banyak dicari serta diminati oleh sebagian pengkonsumsi real food.

Microgreens merupakan kegiatan berkebun yang sangat cocok dilakukan di lingkungan perkotaan karena tidak membutuhkan lahan yang luas, bahan dan alat dapat dengan mudah didapatkan dipasaran, penanaman yang tidak sulit, serta membutuhkan waktu yang singkat [3]. Kegiatan budidaya microgreens memiliki efek terapeutik pada kesehatan mental, mengalihkan fikiran, menimbulkan efek menenangkan, mengurangi gejala stress seperti tekanan darah tinggi, serta membantu merasa berdamai dengan diri sendiri [14].

Selada menjadi salah satu sayuran dari famili Asteraceae yang bisa dibudidayakan secara microgreens. Selada cocok untuk budidaya microgreen karena mudah didapatkan, harga benih yang terjangkau, juga merupakan sayuran yang sudah familiar di kalangan masyarakat. Beberapa jenis tanaman khas Indonesia dapat dibudidayakan menjadi microgreens yang memiliki nilai gizi tinggi dibandingkan microgreens impor [14].

Microgreens selada memiliki kandungan $\mathrm{Ca}, \mathrm{Mg}, \mathrm{Na}, \mathrm{Fe}, \mathrm{Zn}$ yang lebih banyak dibanding dengan selada dewasa [26]. Namun belum ada yang meneliti tentang pigmen yang terkandung pada microgreens selada.

Klorofil, karotenoid, dan antosianin merupakan pigmen penghasil warna yang berperan sebagai antioksidan dalam tubuh. Klorofil merupakan pigmen berwarna hijau yang berfungsi untuk proses fotosintesis [22]. Karotenoid merupakan pigmen berwarna kuning, jingga, atau merah. Karotenoid dikenal sebagai perkusor vit $A$ untuk megurangi penyakit mata [11]. 
Antosianin merupakan senyawa yang memberikan warna merah, biru, atau ungu pada bunga, buah, dan sayuran. Mengonsumsi antosianin pada wanita sebanyak 19,8-64,9 mg dan pada pria sebanyak 18,4 - 44,1 mg setiap hari selama 12 minggu dapat menurunkan kadar kolesterol sebanyak 13,6 \% [25].

Pigmen warna tersebut dapat terbentuk karena ketersediaan air yang cukup, kadar N dan P yang diserap tanaman, cahaya matahari, serta genetik tanaman itu sendiri. Media tanam sangat mempengaruhi ketersediaan air untuk tanaman, juga ketersediaan unsur $\mathrm{N}$ dan $\mathrm{P}$ pada media tanam. Media yang cocok untuk digunakan dalam budidaya microgreens yaitu media yang memiliki porositas yang baik, dapat menyimpan air dan dapat menjaga kelembaban. Media tanam mempengarhi proses penyerapan hara untuk proses metabolisme. Metabolisme merupakan proses fotosintesis yang menghasilkan zat untuk pertumbuhan tanaman serta pembentukan senyawa-senyawa fitokimia dalam tanaman.

Media tanam yang akan digunakan dalam penelitian ini yaitu cocopeat, vermikulit, perlite serta arang sekam. Keempat media tersebut mampu menyimpan air lebih banyak, steril, dan dapat digunakan kembali. Sehingga media tanam tersebut dapat menjadi media yang baik untuk tanaman.
Hasil penelitian Ikrarwati [10], bahwa media vermikulit dengan jarak lampu LED 20 $\mathrm{cm}$ menghasilkan pertumbuhan dan kadar klorofil tertinggi untuk microgreens basil. Namun besarnya kadar klorofil tersebut belum diketahui pada microgreens selada.

\section{METODE}

\section{Bahan dan Alat}

Bahan yang digunakan dalam penelitian ini adalah benih selada, cocopeat, vermikulite, perlite, arang sekam, dan $\mathrm{AB}$ mix. Alat yang digunakan dalam penelitian ini adalah pot plastic ukuran $10 \mathrm{~cm}$, nampan plastik, botol spray, kain kasa, EC meter/TDS Meter, Ph meter, timbangan, meteran/mistar, kamera.

\section{Rancangan Penelitian}

Penelitian ini menggunakan Rancangan Acak Kelompok (RAK) satu faktor yang terdiri dari 4 perlakuan dan 5 ulangan, sehingga diperoleh 20 satuan percobaan. Perlakuan Media Tanam (M) yang terdiri dari 4 taraf, yaitu M1 (Cocopeat), M2 (Vermikulite), M3 (Perlite), dan M4 (Arang Sekam).

\section{Prosedur Penelitian}

\section{Persiapan Media Tanam}

Media tanam yang digunakan yaitu cocopeat, vermikulite, perlite, serta arang sekam. Masing-masing media diisi ke dalam pot berukuran $10 \mathrm{~cm}$ hingga penuh. Setiap 
satu pot merupakan satu ulangan, sehingga pada masing-masing media memerlukan 4 pot plastik. Basahi media tanam dengan air hingga lembab.

\section{Pengenceran Laturan Nutrisi}

Pengenceran nutrisi $A B$ mix dilakukan dengan cara melarutkan nutrisi yang terdiri dari stok A dan stok B. larutkan $5 \mathrm{ml}$ stok $\mathrm{A}$ dengan $1 \mathrm{~L}$ air, begitu juga dengan stok B pada wadah yang berbeda. kemudian campurkan kedua larutan tersebut kedalam satu wadah, lalu diukur dengan TDS meter hingga konsenrasi larutan 500 ppm.

\section{Penyemaian Benih}

Benih diseleksi terlebih dahulu dengan cara merendam benih dalam air hangat selama 15 menit. Benih yang digunakan adalah benih yang tenggelam. Penyemaian dilakukan sebaiknya pada pagi atau sore hari, benih disebar pada permukaan media tanam tanpa ditutup kembali dengan media. Setelah itu semprot benih selada dengan air larutan nutrisi yang sudah dibuat dengan menggukanan botol spray. Benih disemai sebanyak 100 butir benih selada di setiap pot.

\section{Pemeliharaan}

Pemeliharaan yang dilakukan adalah melakukan penyiraman minimal 2 hari sekali menggunakan botol spray dengan larutan
$A B$ mix yang berkonsentrasi 500 ppm. Selain itu diberikan pula larutan $A B$ mix pada wadah baki sebanyak $200 \mathrm{ml}$ tiap nampan dengan jarak pemberian 2 hari sekali agar kelembaban media tetap terjaga

\section{Pemanenan}

Pemanenan dilakukan setelah 10 hari setelah semai (HSS), yang dilakukan dengan cara memotong batang taman sekitar $5 \mathrm{~mm}$ dari permukaan media.

\section{Variabel Pengamatan}

Variabel Pengamatan yang diukur dalam penelitian ini adalah Persentase Perkecambahan (\%), Tinggi Tanaman $(\mathrm{cm})$, Jumlah Daun (helai), Berat Basah (g), Kadar Klorofil (mg/g), Kadar Karotenoid (mg/g), Kadar Antosianin (mg/g).

\section{Analisis Data}

Data yang sudah diperoleh kemudian diolah dengan menggunakan analisis varians ANOVA denga taraf signifikan $5 \%$. Apabila $\mathrm{F}$ hitung $\geq \mathrm{F}$ tabel, maka terdapat pengaruh perbedaan media tanam terhadap pertumbuhan dan kadar pigmen (klorofil, karotenoid, dan antosianin) microgreens selada. Oleh karena itu dilanjutkan dengan uji BNT $5 \%$ untuk melihat perlakuan mana yang terbaik dalam penelitian ini. 


\section{HASIL DAN PEMBAHASAN}

Persentase Perkecambahan

Perlakuan media tanam berpengaruh sangat nyata terhadap persentase perkecambahan microgreens selada pada semua umur pengamatan. Ratarata persentase perkecambahan dapat dilihat pada Tabel 1.

Saat usia tanaman 10 HSS jumlah benih yang berkecambah paling banyak yaitu pada media vermikulit dengan persentase $(84,05 \%)$ dan tidak berbeda dengan cocopeat dengan persentase $(83,0 \%)$. Benih yang ditanam pada media perlite dan arang sekam menunjukkan hasil yang kurang baik, dengan persentase perkecambahan arang sekam sebanyak
$(69,6 \%)$ dan persentase perkecambahan perlite sebanyak $(70,80 \%)$.

Hal ini disebabkan karena vermiculite memiliki kapasitas penyimpanan air yang tinggi, sesuai dengan pendapat [8], yaitu sebesar 337 \% dari berat keringnya. Sedangkan cocopeat memiliki kadar air 119 $\%$ dan daya serap air sebesar 695,4 \% [6].

Dengan kapasitas penyimpanan air yang besar itu, cocopeat dan vermikulit menjadi media yang paling cocok untuk proses perkecambahan. Karena air merupakan hal yang paling dibutuhkan dalam proses perkecambahan. Sehingga ketersediaan air pada media tanam sangat berpengaruh terhadap kemampuan kecambah pada benih.

Tabel 1. Pengaruh Media Tanam Terhadap Persentase Perkecambahan

\begin{tabular}{lccccc}
\hline \multirow{2}{*}{ Perlakuan } & \multicolumn{5}{c}{ Persentase Perkecambahan (\%) } \\
\cline { 2 - 6 } & 2 HSS & 4 HSS & 6 HSS & 8 HSS & 10 HSS \\
\hline P1 ( Cocopeat) & $54.20 \mathrm{~d}$ & $74.20 \mathrm{~d}$ & $82,20 \mathrm{~b}$ & $82,60 \mathrm{~b}$ & $83,00 \mathrm{~b}$ \\
P2 (Vermikulit) & $47.20 \mathrm{c}$ & $71.60 \mathrm{c}$ & $79,80 \mathrm{~b}$ & $81,90 \mathrm{~b}$ & $84,05 \mathrm{~b}$ \\
P3 ( Perlite ) & $40.00 \mathrm{~b}$ & $55.40 \mathrm{~b}$ & $67,20 \mathrm{a}$ & $69,00 \mathrm{a}$ & $70,80 \mathrm{a}$ \\
P4 ( Arang Sekam) & $35.00 \mathrm{a}$ & $48.60 \mathrm{a}$ & $67,40 \mathrm{a}$ & $68,60 \mathrm{a}$ & $69,60 \mathrm{a}$
\end{tabular}

Keterangan : Angka-angka yang diikuti huruf yang sama pada kolom yang sama berarti tidak berbeda nyata menurut uji BNT 5\%

Vermikulit bisa digunakan dalam bidang konstruksi, pertanian, pasar hortikultura, hingga industri. Vermikulit dapat meningkatkan volume, drainase, dan aerasi dari media perakaran. Sifat yang dimiliki oleh vermikulit antara lain, ringan, tidak mudah terbakar, kompresibel, tidak reaktif, dan tidak berbau [8].

\section{Jumlah Daun (helai)}

Perhitungan jumlah daun dilakukan sebanyak 4 kali dengan selang waktu 2 hari 
sekali yaitu pada 4 HSS, 6 HSS, 8 HSS, dan 10 HSS. Perlakuan media tanam tidak berpengaruh nyata terhadap jumlah daun microgreens pada semua umur pengamatan.

Berdasarkan data pada tabel 2, saat usia microgreens 10 HSS, jumlah daun terbanyak dihasilkan oleh media cocopeat dengan rata-rata 3,70 helai dan jumlah daun paling sedikit dihasilkan oleh media arang sekam dengan rata-rata 3,60 helai. Terlihat pertumbuhan jumlah daun mengalami kenaikan secara konstan dan bersamaan. Sama seperti tinggi tanaman, jumlah daun juga dipengaruhi oleh unsur nitrogen dan posfor. Dimana kedua unsur tersebut sudah tersedia pada masing-masing media tanam, juga pada tambahan nutrisi $A B$ mix.
Tidak hanya unsur $\mathrm{N}$ dan $\mathrm{P}$, pertumbuhan jumlah daun ada kaitannya dengan intensitas cahaya yang diterima oleh tanaman. Semakin banyak jumlah intensitas cahaya yang diterima, semakin banyak pula jumlah daun yang dihasilkan. Hal ini terjadi karena adanya proses metabolisme, yaitu proses pembentukan dan penguraian bahan makanan menjadi unsur organik yang digunakan untuk pertumbuhan tanaman [18]. Tidak ada perbedaan intensitas cahaya matahari yang diterima oleh microgreens, sehingga perumbuhan jumlah daun menunjukkan hasil yang sama.

Tabel 2. Pengaruh Media Tanam Terhadap Jumlah Daun

\begin{tabular}{lcccc}
\hline \multirow{2}{*}{ Perlakuan } & \multicolumn{4}{c}{ Jumlah Daun (helai) } \\
\cline { 2 - 5 } & $4 \mathrm{HSS}$ & $6 \mathrm{HSS}$ & $8 \mathrm{HSS}$ & $10 \mathrm{HSS}$ \\
\hline P1 ( Cocopeat) & $1.28 \mathrm{a}$ & $1.98 \mathrm{a}$ & $3.10 \mathrm{a}$ & $3.70 \mathrm{a}$ \\
P2 (Vermikulit) & $1.32 \mathrm{a}$ & $1.94 \mathrm{a}$ & $2.99 \mathrm{a}$ & $3.68 \mathrm{a}$ \\
P3 ( Perlite ) & $1.30 \mathrm{a}$ & $1.84 \mathrm{a}$ & $3.02 \mathrm{a}$ & $3.64 \mathrm{a}$ \\
P4 ( Arang Sekam) & $1.36 \mathrm{a}$ & $1.92 \mathrm{a}$ & $3.00 \mathrm{a}$ & $3.60 \mathrm{a}$
\end{tabular}

Keterangan : Angka-angka yang diikuti huruf yang sama pada kolom yang sama berarti tidak berbeda nyata menurut uji BNT 5\%.

\section{Tinggi Tanaman $(\mathrm{cm})$}

Tabel 3. Pengaruh Media Tanam Terhadap Tinggi Tanaman (cm)

\begin{tabular}{lccccc}
\hline \multirow{2}{*}{ Perlakuan } & \multicolumn{5}{c}{ Tinggi Tanaman (cm) } \\
\cline { 2 - 5 } & 2 HSS & 4 HSS & 6 HSS & 8 HSS & 10 HSS \\
\hline P1 ( Cocopeat) & $0.48 \mathrm{a}$ & $1.93 \mathrm{~b}$ & $3.95 \mathrm{~b}$ & $5.85 \mathrm{~b}$ & $8.01 \mathrm{~b}$
\end{tabular}




$\begin{array}{llllll}\text { P2 ( Vermikulit) } & 0.50 \mathrm{a} & 2.04 \mathrm{c} & 4.17 \mathrm{c} & 6.28 \mathrm{c} & 8.16 \mathrm{~b} \\ \text { P3 ( Perlite ) } & 0.48 \mathrm{a} & 1.91 \mathrm{~b} & 3.74 \mathrm{a} & 5.55 \mathrm{a} & 7.82 \mathrm{a} \\ \text { P4 ( Arang Sekam) } & 0.49 \mathrm{a} & 1.80 \mathrm{a} & 3.63 \mathrm{a} & 5.36 \mathrm{a} & 7.78 \mathrm{a}\end{array}$

Keterangan : Angka-angka yang diikuti huruf yang sama pada kolom yang sama berarti tidak berbeda nyata menurut uji BNT 5\%.

Pengukuran tinggi tanaman dilakukan sebanyak 5 kali dengan selang waktu 2 hari sekali yaitu pada 2 HSS, 4 HSS, 6 HSS, 8 HSS, dan 10 HSS. Tinggi tanaman diukur dengan menggunakan mistar dari pangkal batang hingga ujung daun. Perlakuan media tanam berpengaruh sangat nyata terhadap tinggi microgreens pada umur pengamatan 4, 6, 8, dan 10.

Pada Tabel 3. bahwa media yang terbaik untuk tinggi tanaman yaitu vermikulit dan tidak berbeda dengan cocopeat. Saat microgreens berusia 2 HSS tinggi tanaman masih belum terdapat perbedaan yang nyata. Hal ini disebabkan benih yang baru berkecambah masih menggunakan cadangan makanan yang tersedia pada benih tersebut dan belum menggunakan nutrisi tambahan atau nutrisi pada media tanam. Pertumbuhan tinggi tanaman dipengaruhi oleh unsur nitrogen dan posfor. Selain dari media itu sendiri, kedua unsur tersebut didapatkan dari penambahan larutan nutrisi $A B$ mix.

Kemudian saat 4, 6,dan 8 HSS, media vermikulite menghasilkan tanaman yang lebih tinggi dibandingkan media lain.
Larutan stok $\mathrm{A}$ terdiri atas unsur $\mathrm{N}$, $\mathrm{K}, \mathrm{C}$ dan $\mathrm{Fe}$, dimana unsur nitrogen sangat berperan dalam penbentukan sel tanaman, jaringan, dan organ tanaman. oleh karena itu, nitrogen dibutuhkan dalam jumlah yang cukup besar, terutama pada saat masa vegetatif. Sedangkan larutan stok $B$ mengandung unsur $\mathrm{P}, \mathrm{Mg}, \mathrm{S}, \mathrm{B}, \mathrm{Mn}, \mathrm{Cu}, \mathrm{Na}$, Mo, dan Zn. [12].

Selain nutrisi dari $A B$ mix, terdapat nutrisi tambahan dari media tanam itu sendiri. Arang sekam mengandung $\mathrm{SiO}_{2}$ (52\%), C (31\%), K (0,3 \%), N (0,18\%), P $(0,08 \%)$, dan Ca $(0,14 \%)$ (Kusuma et al., 2013) sedangkan cocopeat mengandung unsur hara antara lain N 0,31\%, P 0,15\%, K 0,31\%, Ca 0,96\%, Fe 180 ppm, Mn 80.4 ppm dan Zn 14.10 ppm [4].

Vermikulit dan perlite tidak memiliki kandungan Nitrogen, namun vermikulit memiliki kemampuan penyimpanan air yang tingi, sehingga vermikulit mampu mendapatkan unsur $\mathrm{N}$ yang lebih banyak dari $A B$ mix dibandingkan dengan media lain. Kandungan $\mathrm{N}$ dan $\mathrm{P}$ pada cocopeat lebih banyak dibandingkan dengan arang sekam, sehingga cococpeat dan vermikulit mampu mendapatkan unsur hara lebih 
banyak dibandingkan dengan perlite dan arang sekam.

\section{Berat Basah Tanaman (gr)}

Penimbangan Berat Basah tanaman dilakukan sebanyak 1 kali saat panen yaitu saat tanaman berusia 10 HSS. Berdasarkan analisa sidik ragam, menunjukkan bahwa perlakuan media tanam berpengaruh sangat nyata terhadap berat basah microgreens selada.

Berat basah microgreens juga dipengaruhi oleh berapa banyak benih yang berkecambah. Media tanam memberikan pengaruh sangat nyata terhadap berat basah microgreens selada. Semakin banyak benih yang berkecambah, maka berat microgreens juga akan semakin banyak. Pada persentase perkecambahan, vermikulit menujukkan hasil yang paling baik, begitu pula dengan berat basah microgreens. Sedangkan benih yang paling sedikit berkecambah yaitu arang sekam, maka hasil berat basah terkecil juga dihasilkan pada media arang sekam

Tabel 4. Pengaruh Media Tanam Terhadap Berat Basah microgreens

\begin{tabular}{lc}
\hline Perlakuan & Berat Basah Microgreens Selada (g) \\
\hline P1 ( Cocopeat) & $3.84 \mathrm{~b}$ \\
P2 ( Vermikulit) & $4.61 \mathrm{c}$ \\
P3 ( Perlite ) & $3.88 \mathrm{~b}$ \\
P4 ( Arang Sekam) & $2.68 \mathrm{a}$ \\
\hline Keterangan : Angka-angka yang diikuti huruf yang sama pada kolom yang sama & \multicolumn{2}{c}{ berarti tidak berbeda nyata menurut uji BNT 5\%. }
\end{tabular}

Vermikulit menjadi media yang paling baik dalam variabel berat basah microgreens. Media tanam vermikulit memiliki kapasitas tukar kation yang lebih tinggi terutama dalam keadaan padat dan pada saat basah. Vermikulit mampu menurunkan berat jenis dan meningkatkan daya absorpsi air. Sehingga media tanam yang memiliki keunggulan tersebut bisa menyerap lebih banyak nutrisi saat media direndam dalam air larutan nutrisi $A B$ mix dan cadangan unsur hara yang tersimpan di dalam media dapat lebih mudah diserap oleh akar tanaman untuk mendukung pertumbuhan tanaman [24].

Sebagai media tanam, fungsi perlite sama dengan vermikulit yaitu menurunkan berat jenis dan meningkatkan daya serap air. Namun berbeda dengan vermikulit, perlite merupakan produk mineral berbobot ringan serta memiliki kapasitas tukar kation dan daya serap air yang rendah [7]. Hal tersebut 
diduga sebagai penyebab hasil berat basah microgreen pada media perlite kurang maksimal.

Arang sekam diketahui memiliki porositas yang baik sehingga mudah menyerap air. Namun, media ini juga mudah kehilangan air sehingga nutrisi yang diberikan tidak mampu tersimpan lama dalam media. Air merupakan komponen utama penyusun jaringan tanaman dan sangat berpengaruh terhadap pertumbuhan dan perkembangan tanaman. Ketersediaan air yang lebih rendah akan menghambat pertumbuhan tanaman dan menurunkan kandungan air dalam jaringan tanaman [5].

\section{Kadar Klorofil (mg/g)}

Perlakuan media tanam berpengaruh sangat nyata terhadap kadar klorofil tanaman Berdasarkan Tabel 4. media tanam cocopeat menghasilkan microgreens dengan kadar klorofil terendah sebesar $0.422 \mathrm{mg} / \mathrm{g}$. Hasil kadar klorofil tertinggi dihasilkan oleh media tanam perlite sebesar $\quad 0.812 \mathrm{mg} / \mathrm{g}$ walaupun tidak berbeda dengan media vermikulit $(0,08 \mathrm{mg} / \mathrm{g})$ dan arang sekam $(0,766 \mathrm{mg} / \mathrm{g})$.

Menurut [2], kandungan klorofil dipengaruhi oleh unsur hara nitrogen dan posfor. Kedua unsur tersebut sangat berperan dalam pembentukan sel-sel baru dan komponen utama penyusun senyawa organik dalam tanaman seperti asam amino, asam nukleat, klorofil, ADP dan ATP. Faktor- faktor yang berpengaruh terhadap pembentukan klorofil antara lain gen, oksigen, cahaya, unsur N, P, Mg, Fe sebagai pembentuk dan katalis.

Cocopeat memiliki daya serap air yang tinggi, mampu menyimpan air dengan baik, memiliki kandungan unsur hara yang dibutuhkan tanaman, serta menggemburkan tanah. Menurut [4] cocopeat memiliki kemampuan mengikat dan menyimpan air yang sangat kuat menyebabkan ruang udara yang ada pada media terisi oleh air, sehingga respirasi akar terganggu dan pengangkutan hara dari akar terhambat .

Salah satu kekurangan cocopeat yaitu mengandung zat tannin. Penelitian [23], menyatakan bahwa penyebab rendahnya respon pertumbuhan bibit cempaka wasian adalah adanya zat tannin yang terkandung dalam cocopeat. Zat tersebut merupakan senyawa penghalang mekanis dalam penyerapan unsur hara. Kemudian pada bibit sengon, cocopeat menjadikan ukuran daun lebih kecil dan berwarna kekuning-kuningan.

Menurut [17], bahwa media tanam yang mampu menyerap air dalam volume yang banyak belum tentu dapat dikategorikan sebagai media tanam yang paling baik. Hal ini dikarenakan media tanam dengan kapasitas menahan air yang tinggi dapar mengakibatkan media menjadi jenuh air, sehingga menyebabkan kadar oksigen 
rendah dan kontak tanaman dengan oksigen akan terhambat. Oksigen dibutuhkan oleh tanaman untuk proses metabolisme. Tanaman yang tumbuh pada media cocopeat menghasilkan kadar klorofil terendah. Kadar total klorofil pada daun selada yaitu sebesar $5,23 \mathrm{mg} / \mathrm{L}[20]$.

Tabel 4. Pengaruh Media Tanam Terhadap Kadar Klorofil

\begin{tabular}{ll}
\hline Perlakuan & Kadar Klorofil $(\mathrm{mg} / \mathrm{g})$ \\
\hline P1 ( Cocopeat) & $0.42 \mathrm{a}$ \\
P2 ( Vermikulit) & $0.81 \mathrm{~b}$ \\
P3 ( Perlite ) & $0.81 \mathrm{~b}$ \\
P4 ( Arang Sekam) & $0.77 \mathrm{~b}$ \\
\hline
\end{tabular}

Keterangan : Angka-angka yang diikuti huruf yang sama pada kolom yang sama berarti tidak berbeda nyata menurut uji BNT 5\%.

\section{Kadar Karotenoid (mg/g)}

Perlakuan media tanam berpengaruh sangat nyata terhadap kadar karotenoid microgreens. Sama seperti kadar klorofil, kadar karotenoid terendah dihasilkan oleh tanaman microgreens pada media cocopeat dengan rata-rata $0,062 \mathrm{mg} / \mathrm{g}$. Hasil tertinggi oleh media arang sekam dengan rata-rata $0,120 \mathrm{mg} / \mathrm{g}$, yang tidak berbeda nyata dengan media perlite dengan rata-rata 0,118 $\mathrm{mg} / \mathrm{g}$ dan media vermikulit dengan rata-rata $0,117 \mathrm{mg} / \mathrm{g}$.

Tabel 5. Pengaruh Media Tanam Terhadap Kadar Karotenoid

\begin{tabular}{lc}
\hline Perlakuan & Kadar Karotenoid $(\mathrm{mg} / \mathrm{g})$ \\
\hline P1 ( Cocopeat) & $0.06 \mathrm{a}$ \\
P2 ( Vermikulit) & $0.12 \mathrm{~b}$ \\
P3 ( Perlite) & $0.12 \mathrm{~b}$ \\
P4 ( Arang Sekam) & $0.12 \mathrm{~b}$ \\
\hline
\end{tabular}

Keterangan : Angka - angka yang diikuti huruf yang sama pada kolom yang sama berarti tidak berbeda nyata menurut uji BNT 5\%.

Faktor lingkungan dapat mempengaruhi pembentukan karotenoid, seperti suhu, air, cahaya dan kelembaban. Menurut [9], peran karotenoid dalam fotosintesis adalah 
membantu mengabsorbsi cahaya, sehingga cahaya yang dipakai untuk proses fotosintesis menjadi lebih besar. Energi yang diserap oleh karotenoid diteruskan pada klorofil yang kemudian digunakan dalam fotosintesis. Diduga,karotenoid selain sebagai pigmen fotosintesis juga berfungsi untuk melindungi klorofil dari cahaya tinggi, sehingga kandungan karotenoid pada tanaman menyesuaikan dengan kandungan klorofilnya. Kadar karoten pada selada hidroponik yaitu sebesar 39,6 mg/L [15]. Perbedaan genetik pada setiap tumbuhan akan mempengaruhi kemampuan dalam mensintesis karotenoid. Karotenoid merupakan pigmen asesori pada proses fotosintesis, terletak didalam kloroplas Bersama-sama dengan klorofil [13].

Tabel 6. Pengaruh Media Tanam Terhadap Kadar Antosianin

\begin{tabular}{lc}
\hline Perlakuan & Kadar Antosianin (mg/100g) \\
\hline P1 ( Cocopeat) & $0.036 \mathrm{a}$ \\
P2 ( Vermikulit) & $0.039 \mathrm{a}$ \\
P3 ( Perlite ) & $0.042 \mathrm{a}$ \\
P4 ( Arang Sekam) & $0.034 \mathrm{a}$ \\
\hline
\end{tabular}

Keterangan : Angka-angka yang diikuti huruf yang sama pada kolom yang sama berarti tidak berbeda nyata menurut uji BNT 5\%.

\section{Kadar Antosianin (mg/g)}

Pengujian kadar antosianin dilakukan sebanyak 1 kali saat panen yaitu saat tanaman berusia 10 HSS. Berdasarkan analisa sidik ragam, menunjukkan bahwa perlakuan media tanam tidak berpengaruh nyata terhadap kadar antosianin tanaman.

Pada tabel 6. Kadar antosianin microgreens selada tertinggi yaitu pada media perlite dengan rata-rata 0.042 $\mathrm{mg} / 100 \mathrm{~g}$. Setiap 100 gram microgreens selada, mengandung $0.042 \mathrm{mg}$ senyawa antosianin. Hasil uji tersebut menunjukkan bahwa penanaman microgreens selada menggunakan media apa saja, akan menghasilkan kadar antosianin yang sama besarnya.

Antosianin adalah pigmen yang larut dalam air yang menyebabkan warna merah, ungu, dan biru serta banyak ditemukan pada buah dan bunga [16]. Sehingga, pada sayuran yang berwarna hijau, kadar antosianin tidak menunjukkan hasil yang tinggi.

Kandungan pigmen antosianin tidak lebih besar dari kandungan klorofil, termasuk pada daun yang berwarna merah. Baik daun berwarna hijau atau merah, kandungan antosianinnya akan lebih rendah dibandingkan dengan kandungan 
klorofilnya. Hal itu disebabkan karena klorofil merupakan pigmen utama yang ada pada seluruh tanaman, sehingga meskipun daunnya berwarna merah, tidak berarti bahwa kandungan antosianin lebih tinggi, tetap pigmen klorofil lah yang lebih dominan [27].

Warna antosianin bukanlah sebagai pembeda saja, tetapi juga merupakan informasi penting mengenai nutrisinya. Semakin pekat atau kuat warna yang dihasilkan pada tanaman menunjukkan bahwa semakin besar pula konsentrasi antosianin yang terdapat pada tanaman tersebut [19].

\section{KESIMPULAN}

Perbedaan media tanam memberikan pengaruh yang nyata terhadap parameter persentase perkecambahan, tinggi tanaman, berat basah tanaman, kadar klorofil dan kadar karotenoid. Media tanam yang paling baik untuk microgreens selada adalah vermikulite yang direfleksikan pada parameter persentase perkecambahan, tinggi tanaman, berat basah tanaman, kadar klorofil dan kadar karotenoid.

Saran Penelitian yaitu perlu dilakukan penelitian lanjutan dengan pencampuran beberapa kombinasi media tanam serta perbedaan beberapa konsentrasi $A B$ mix untuk mendapatkan kosentrasi terbaik. Serta perlu dihitung parameter luas daun, untuk mengetahui apakah luasan daun berpengaruh terhadap kemampuan daun menangkap cahaya dan banyaknya kadar pigmen yang dihasilkan.

\section{DAFTAR PUSTAKA}

Adawiyah, A., Cahyanto, T., Salim, M. A., \& Suparman, D. (2020). Bioprospek microgreens sebagai agen antivirus dalam menghambat penyebaran coronavirus disease 2019 (COVID19).

Amini, Z., Eviyati, R., \& Dwirayani, D. (2021, May). Penerapan Urban Agriculture melalui Teknik Budidaya Tanaman Microgreen untuk Mendukung Ketahanan Pangan Keluarga. In Prosiding Seminar Nasional Fakultas Pertanian UNS (Vol. 5, No. 1, pp. 489-494).

Rokhmah, N. A., \& Sapriliani, T. (2021). Respon Pertumbuhan dan hasil Panen Microgreens Pakcoy Pada Nutrisi dan Media yang Berbeda.

Kusumah, A. V. C., \& Nurjasmi, R. (2021). Potensi Microgreens Meningkatkan Kesehatan Lansia Di Masa Pandemi. Jurnal IImiah Respati, 12(1), 1-10.

Weber, C., F. (2016). Nutrient content of cabbage and lettuce microgreens grown on vermicompost and 
hydroponic growing pads. Journal of Horticulture Research, 3(4): 1-5.

Setiawati, T., Saragih, I. A., Nurzaman, M., \& Mutaqin, A. Z. (2016). Analisis Kadar Klorofil dan Luas Daun Lampeni (Ardisia humilis Thunberg) pada Tingkat Perkembangan yang Berbeda di Cagar Alam Pangandaran. In Prosiding Seminar Nasional MIPA 2016 (pp. 122-126).

Iriyani, D., \& Nugrahani, P. (2014). Kandungan klorofil, karotenoid, dan vitamin c beberapa jenis sayuran daun pada pertanian periurban di Kota Surabaya. Jurnal Matematika Sains dan Teknologi, 15(2), 84-90.

Ikrarwati, F. N. U., Zulkarnaen, I., Fathonah, A., Nurmayulis, F. N. U., \& Eris, F. R. (2020) Pengaruh Jarak Lampu LED dan Jenis Media Tanam Terhadap Microgreen Basil (Ocimum basilicum L.). In Agropross: National Conference Proceedings of Agriculture (pp. 15-25).

Hasriani, D. Kusnadi, dan A. Saputra, (2013). Kajian Serbuk Sabut Kelapa (Cocopeat) Sebagai Media Tanam. Departemen Teknik Sipil dan Lingkungan. Fakultas Teknologi Pertanian. IPB. Bogor.
Hendry, Dewi Amalia. (2014). Stabilisasi Tanah Lempung Padalarang Menggunakan Vermikulit dan Semen untuk Menungkatkan daya Dukung (UCS). PROKONS: Jurusan Teknik Sipil, 8(1), 19-32.

Pertamawati. 2010. Pengaruh Fotosintesis Terhadap Pertumbuhan Tanaman Kentang (Solanium Tuberosum L.) dalam Lingkungan Fotoautrotrof Secara Invitro. Jurnal Sains dan Teknologi Indonesia. 12(1): 31-37.

Arjuna, Syaiful, A. A., \& Ulfa, F. (2017). Pertumbuhan dan Produksi Tanaman Bawang Merah (Allium ascalonicum L.) Secara Hidroponik pada Berbagai Media dan Konsentrasi Air Kelapa sebagai Zat Pengatur Tumbuh. Agrotan, 3(2), 111.

Suryani, R. (2015). Hidroponik budidaya tanaman tanpa tanah. Yogyakarta: Arcitra.

Rahmi, A. (2017). Kandungan Klorofil pada Beberapa Jenis Tanaman Sayuran sebagai Pengembangan Praktikum Fisiologi Tumbuhan. Skripsi. Universitas Islam Ar-Raniry.

Kurniawan, M., Izzati, M., \& Nurchayati, Y. (2010). Kandungan klorofil, karotenoid, dan vitamin C pada 
Jurnal IImiah Respati

beberapa spesies tumbuhan

akuatik. Anatomi Fisiologi, 18(1), 28-

40.

Priska, M., Peni, N., Carvallo, L., \& Ngapa, Y.

D. (2018). Antosianin dan

pemanfaatannya. Cakra Kimia

(Indonesian E-Journal of Applied

Chemistry), 6(2), 79 
